\title{
THE CREATION OF AN AFRICAN CIVIL SERVICE IN KENYA
}

\author{
BY VOLKer VinNaI
}

The discussion on localization ${ }^{1}$ in newly independent African states has so far concentrated on economic aspects. The localization strategy applied to industry in the face of a foreign owned industrial sector is here the best example. Another aspect of localization, the nationalization of commerce through the elimination of non-citizen traders has been highlighted recently through the expulsion of the Asians from Uganda in the latter part of 1972 and the less spectacular exclusion of Asians in commerce currently underway in Kenya. Less interesting, but by no means less significant is the localization of the Civil Service, the change-over of a colonial administration staffed by European civil servants and responsible to a Governor for the maintenance of domestic peace and the enhancement of an export enclave for minerals or agricultural produce - if possible at no cost to the tax-payer in the metropolitan-country - to a larger and more complex "interventionist" administration staffed by citizens directed by elected ministers trying to perform for its population the enlarged functions of an independent modern government.

In the following the discussion centers on the localization of the central administration in Kenya - its transfer from British civil servants into the hands of citizens, almost exclusively Africans.

\section{The Colonial Civil Service}

The civil service in British Commonwealth countries was essentially set up to act as an agent of the Colonial Office for implementing a government policy decided on in London". The service was "geared to the rather negative policy of preventing trouble and bringing the Pax Britannica to all the dependent territories overseas. It was not, until comparatively recently, concerned with economic and social development as a major objective of administration. Economic services were lacking in strength and purpose. Except where immigrant populations had settled, there were no developments towards industrialization. The central administration had no positive policy towards the promotion of these economic services except to create the conditions under which private enterprise could flourish, and to intervene where necessary to ensure fair play to the unsophisticated people of the territories ${ }^{3}$ “"

\footnotetext{
1 Localization in its broadest sense is the transfer of economic power, either through replacement of foreign personnel or through acquisition of foreign owned-assets, in the hands of citizens. In Kenya with its multiracial society the term "Kenyanization" is normally used in official publications. In contrast to "Kenyanization" the term "Africanization" is generally used for policies designed to enhance the advancement of African citizens as against Asian or European citizens of Kenya.

2 For a general discussion of the British Colonial Civil Service, see: A. L. Adu, The Civil Service in New African States, Washington, 1969 (revised edition), and, The Civil Service in Commonwealth Africa-Development and Transition, London, 1969; K. Younger, The Public Service in the New States, London, 1960; Richard Symonds, The British and Their Successors - A Study in the Development of the Government Services in the New States, London, 1966.

3 Adu.: Civil Service in New African States, p. 15.
} 
To fulfil these objectives, which expressed themselves in Kenya primarily in the collection of revenue to make the colony self-supporting for the maintenance of law and order and the creation of favourable conditions for the White agricultural sector and its supporting infrastructure, the Service relied mainly on European personnel recruited overseas. Europeans filled all senior posts responsible for administrative, executive, professional and technical grades. Local personnel were recruited to fill junior positions - clerical, semi-skilled and unskilled grades as well as some junior executive posts.

The issue of localization of the civil service, the hiring of nationals of the resprective overseas territories, was one that confronted the Colonial Office as soon as an administrative machinery was set up. It was far too expensive to fill all administrative posts with Europeans. Simple budgetary constraints forced the recruitment of local personnel to fill junior posts 4 .

In East Africa this policy of localization led to a three-tier differentiation along racial lines. Europeans filled the top posts, the middle level was occupied by immigrant Asians, whereas Africans were recruited for the jobs at the bottom. This racial division reflected itself also in separate housing arrangements, social clubs and service facilities like hospitals, schools, etc. Moreover, the availability of a supply of educated Asian candidates relieved the Government of the responsibility to educate and train Africans to fill the subordinate positions in the civil service.

This division along racial lines led also to a differential pay scale according to race, whose justification was given by the situation on the local labour market with which the service had to compete, "where the most highly paid posts, usually calling for professional technical qualifications are filled by Europeans, the less well paid posts by Asians and the least well paid by Africans.".

Yet even where two candidates of different races held the same qualifications, the Asian earned less than the European and the African less than the Asian ${ }^{6}$. As the Holmes Report put it: "Subject to individual exceptions the African is at present markedly inferior to the Asian of the same educational qualifications in such matters as sense of responsibility, judgement, application to duty and output of work"7, a view that received "the overwhelming endorsement" of the persons heard by the Committee ${ }^{8}$. As far as the European was concerned, he "surpasses the Asian in such matters as sense of public service, judgement and readiness to take responsibility ${ }^{\prime \prime}$

This division along racial lines is evident in the structure of the Service in 1961, when over $40 \%$ of all posts which demanded an education were held by Asians, even though the Asian community in Kenya numbered only $2 \%$ of the total population of Kenya ${ }^{10}$.

4 The debate on localization in India started already early in the 19th century - Symonds, The British and Their Successors, Chapter I, pp. 25-43.

5 Report of the Commission on the Civil Services of Kenya, Tanganyika, Uganda and Zanzibar 1947-1948

6 The Holmes Report of $1947 / 48$ introduced for equal positions a $3 / 5$ wage differential based on race, and a $4 / 5$ wage differential based on sex.

7 Ibid., p. 24.

8 Ibid., p. 25

9 Ibid., p. 25.

10 The 1962 population census counted 8,366,000 Africans, 177,000 Asians and 56,000 Europeans-Government of Kenya, Statistical Abstract 1972, Table II, p. 13. 


\begin{tabular}{lrrr} 
& European & Asian & African \\
\hline Positions which demand higher education* & 1250 & 450 & 180 \\
Positions which demand secondary education & 1900 & 2600 & 900 \\
\hline ( $^{*}-$ except teachers) & 3150 & 3050 & 1080
\end{tabular}

Source: Symonds, The British and Their Successors, p. 176.

At the lower level, a large number of salaried Africans were employed, so that by 1960 about $80 \%$ of the entire Civil Service consisted of indigenous personnel ${ }^{11}$.

Before 1960 very few posts of any responsibility were occupied by Africans. In 1960, for example, only five out of 228 officers of the rank of District Officer and upwards were Africans ${ }^{12}$. Undoubtedly their absence in the higher levels of the service was to a great extent due to the absence of educational facilities for Africans in Kenya ${ }^{13}$. However, the main reason for the predominance of Whites in the service prior to 1960 must be seen in the presence of the settler community. For the average White farmer the idea of an African holding a position of responsibility or one with executive powers was repugnant. In the emergency situation of the 1950s, the colonial administration was unwilling to antagonize the White settlers by giving responsible posts to Africans, especially to Kikuyus ${ }^{\mathbf{1 4}}$. Under these circumstances it is easily understandable that an African would not train for a job which he could not get.

Only after the independence of Ghana February (1957) and other West African states was the need for Africanization as opposed to localization of middle and high level positions in Kenya realized by the colonial government. Barriers for African advancement were removed and a unified salary scale introduced for all races. The policy of multi-racialism of the late $50 \mathrm{~s}$ was to give the best man a chance to get to the top. Personnel from outside the Colony were only to be recruited if no suitable local candidates could be found. After 1960, expatriates were only to be employed on contract and not on a permanent basis ${ }^{15}$. In 1961 the colonial administration finally started to train Africans to replace the key administrative cadre composed of Europeans ${ }^{16}$.

11 The entire service consisted in the same year of $10 \%$ Europeans, $8 \%$ Asians and Arabs, and $82 \%$ Africans. Internationa! Bank for Reconstruction and Development, The Economic Development of Kenya, Nairobi 1962, p. 8 (hereafter referred to as IBRD Report).

12 A. L. Adu, Statting and Training the Federal Civil Service, Nairobi, 1963, p. 9.

13 A point that aill be discussed later on. White settlers in Kenya; see for the early colonial period: M. Sorrenson, Origins of European Settlement in Kenya, Nairobi, 1968; for the later period, especially: So Rough a Wind - The Kenya Memoirs of Sir Michael Blundell, London, 1964, and Carl Rosberg Jr. and John Nottingham, The Myth of the Mau Mau - Nationalism in Kenya, Nairobi, 1966.

15 For details see:

- Report of the Commission on the East African Territories and East African High Commission 1953:54 (Lidbury Report), London, 1954.

- Report of the Commission on the Public Services of the East African Territories and the East African High Commission (Flemming Report), Entebbe, 1960.

- Report on the Localization of the Civil Service of the East African High Commission (Ramage Report), Nairobi, 1961.

16 Report of the Commission of Iniquiry - Public Service Structure and Renumeration Commission 1970-1971, (Ndegwa Report), Nairobi, 1971, p. 9. 
The racial breakdown of the service (Kenya Civil Service, E. A. Posts and Telecommunication, General Fund of the East African Common Service Organization) at the beginning of this second phase of localization is given below:

Racial Breakdown of the Kenya Civil Service as at 1. July 1962

\begin{tabular}{|c|c|c|c|c|c|c|c|c|c|}
\hline \multirow[b]{2}{*}{ Administrative Class } & \multicolumn{3}{|c|}{$\begin{array}{c}\text { European } \\
\text { P.O.a C.O.b T.O.c }\end{array}$} & \multirow{2}{*}{ P.O. } & \multirow{2}{*}{$\begin{array}{c}\begin{array}{c}\text { Asian } \\
\text { C.O. }\end{array} \\
5\end{array}$} & \multirow{2}{*}{$\frac{\text { T.O. }}{1}$} & \multirow{2}{*}{\multicolumn{2}{|c|}{$\begin{array}{c}\begin{array}{c}\text { African } \\
\text { C.O. }\end{array} \\
2 \quad 42\end{array}$}} & \multirow{2}{*}{ T.O. } \\
\hline & 338 & 14 & 15 & & & & & & \\
\hline Professional Class & 798 & 45 & 181 & 109 & 44 & 23 & 74 & 11 & 3 \\
\hline General Executive Class & 165 & 45 & 40 & 645 & 7 & 7 & 93 & 16 & 1 \\
\hline $\begin{array}{l}\text { Departemental Executive } \\
\text { Class }\end{array}$ & 272 & 28 & 46 & 218 & 4 & 2 & 173 & 18 & 4 \\
\hline $\begin{array}{l}\text { Departemental Technical } \\
\text { Class }\end{array}$ & 760 & 74 & 309 & 280 & 6 & 41 & 142 & 33 & 59 \\
\hline Semi-Professional Class & 29 & 2 & 9 & 16 & 1 & 10 & 11 & - & 3 \\
\hline $\begin{array}{l}\text { Personal Secretaries and } \\
\text { Stenographer Secretaries }\end{array}$ & 54 & 176 & 26 & 25 & 69 & 12 & 2 & 3 & 一 \\
\hline Nursing Class & 100 & 72 & 46 & 12 & 8 & 9 & 951 & 99 & $\therefore$ \\
\hline Police Uniformed Service & 644 & 5 & 9 & 91 & - & - & 10867 & - & 583 \\
\hline Prisons Uniformed Service & 93 & 4 & 3 & 6 & 1 & - & 3844 & 4 & 30 \\
\hline Teaching Class & 102 & 147 & 56 & 848 & 173 & 6 & 304 & 72 & 1 \\
\hline Clerical and Typing & 50 & 209 & 11 & 1289 & 223 & 20 & 2041 & 655 & 18 \\
\hline Technical Class & 14 & 30 & 18 & 297 & 43 & 44 & 2684 & 1577 & 13 \\
\hline Others-Miscellaneous & - & 67 & - & 76 & 11 & 1 & 3.079 & 1486 & 12 \\
\hline Subordinate Service & - & - & - & - & - & - & 5230 & 16102 & - \\
\hline Total & 3365 & 918 & 769 & 3918 & 595 & 176 & 29567 & 29118 & 728 \\
\hline
\end{tabular}

a - Pensionable Officers

b - Contract Officers

c - Temporay Officers

Source: Report of the Local Civil Service Salaries Commission (Pratt Report), Nairobi, 1963, Table II, p. 136.

The Africanization of the service depended, however, on the availability of qualified candidates, which in turn depended on the educational system. And here Africans had been greatly neglected in the past. Even though Kenya provided some primary education for Africans, mostly in missionary schools, the bottleneck was in secondary and higher education ${ }^{17}$. In 1958 only $13 \%$ of those who completed eight years of primary school could find a place in a secondary school. In the same year 219 Africans studied abroad, 294 at Makerere College in Kampala, Uganda and 50 at the Technical College in Nairobi ${ }^{13}$.

\footnotetext{
17 For a discussion on education in Kenya prior to independence see: Guy Hunter, Education for a Developing Region - a Study of East Africa, London, 1963

18 Tom Mboya, Freedom and After, London 1963, pp. 142, 143; also Education Department, Triennal Survey 1953-1960, p. 36.
} 
The educational pyramid of African primary and secondary school pupils was rather steep. In 1962 around 150000 pupils entered primary school, but only 25000 completed it. Of these, 2100 boys and 600 girls were admitted into second ary school, but only 200 boys, but no girl graduated ${ }^{19}$.

A conflicting source mentions for the same year that 918 African boys and 54 girls passed the Cambridge School Certificate, while 195 Africans studied in Britain, another 110 in India and Pakistan. Others studied in the United States20 under the African Scholarship Programme, introduced in 1960, which offered places to Africans at 213 American colleges and universities ${ }^{21}$.

Despite the inconsistency between these two sources, the lack of educated Africans to occupy positions of responsibility in the service is evident. The colonial educational system was set up for the children of the expatriates and denied higher education to Africans, who were therefore effectively barred to play any important role in the administration.

One of the results of the First Independence Conference of 1960 at Lancaster House in London was the decision for the localization of the civil service at the greatest speed consistent with the maintenance of efficient standards. Fundamental to the success of localization was the existence of a special training institute for the higher cadres of the service. Thus, in July 1961 the Kenya Institute of Administration ${ }^{22}$ was opened to provide a training crash programme for indigenous manpower ${ }^{23}$.

With internal self government achieved in June 1963 and formal independence in December of the same year, the policy of Africanization, the transformation of a colonial service with limited functions into a national service geared to economic and social development of the country ${ }^{24}$, was greatly accelerated.

\section{The African Civil Service}

For the newly independent Kenya, political considerations dictated the creation of an indigenous civil service. Sensitive positions affecting security, such as key posts in the police ${ }^{25}$, the armed forces ${ }^{26}$, the Ministry of Defense and the ministry of Interior had to be filled with Africans. Also, national pride demanded

19 IBRD, 1962, pp. $156 / 157$ and 163.

20 Tom Mboya, Freedom and After, p. 144. In 19623690 students from Kenya studied abroad, of whom only 1,576 were Africans. The rest were mainly Asians, who received their education through private means - Education Department, Triennial Survey 1961-1963, p. 34.

21 By 1963 the ASPAU Programme had brought 503 students from 24 African countries to the US and planned to bring another 300 in 1963 - Tom Mboya, Freedom and After, p. 144.

22 A. J. F. Simmance, “The Kenya Institute of Administration" in: Journal of Local Administration Overseas, Vol. III No. 3, (July 1964) pp. 164-168. For an evaluation of the KIA see: Colin Leys/ Patricia Stamp, Organization and Development - Dilemmas of Administrative. Training in Kenya, mimeo, n. d. Chapter VII; E. C. Cunningham Sinclair, Administrative Training in Kenya, MA thesis, Nairobi, 1968.

23 E. K. Nibogor: "The problems of senior staff development in Kenya, the role of the Kenya Institute of Administration, in: African administrative studies No. 10 (November 1973), p. 262.

24 For two policy statements on the role of the African civil service see: D. N. Ndegwa, "The Civil Servant in the New Kenva", in: Administration in Kenya, Journal of the Kenya Institute of Administration, No. 1, (December 1965), pp. 3-7; and Tom Mboya, The Role of the Civil Service in Developing Countries, in: The Challenge of Nationhood, London, 1970, pp. 162-167.

25 One year ifter independence, an African became head of the police force - Oginga Odinga, Not yet Uhuru, London 1967, p. 247.

26 The East African defense force, the Kings African Rifles, were recruited mainly from Kambas, one of the minor tribes in Kenya. In 1961 the Kenyan force had only European and Asian officers, since no suitable African could be found. With the events in the Congo in mind, the qualifications for African suitable African could be found. With the events in the Congo in mind, the qualifications for African
officers were lowered and NCO's sent to England to be trained as officers. By April 1963, six months before independence, Kenya had 84 African officers, about half of the officer corps - Symonds, The British and their Successors, p. 185. 
the establishment of an African foreign service. Economic considerations such as the higher costs of expatriate personnel and the outflow of foreign exchange through expatriate officers were other considerations. Finally, Africanization was to ensure a stability of staff.

As a consequence of this need for rapid Africanization, compulsory ${ }^{27}$ and voluntary retirement of British civil service officers was introduced, even if the standard of the administration had to be lowered.

Already by 1965 , virtually the entire administrative cadre was filled with Kenya citizens ${ }^{28}$. Shortly after independence, Kenya could boast of an African civil service, even though this service was very British in outlook and behaviour.

This speedy Africanization led unfortunately to three long term consequences. First, the forcible retirement of British civil servants created a large financial committment for the new state. Like other British colonies, Kenya had to agree during the independence negotiations to pay very generous compensations ${ }^{29}$ to the retiring expatriate officers. According to the Fiscal Commission Report of 1963, some 3020 expatriate civil servants were to receive for over six years (from $1962 / 63$ to $1968 / 69$ ) a compensation totalling $£ 35.5$ million of which Kenya had to provide 21.7 million. As in the case of the compensation paid to European farmers ${ }^{30}$, these payments were partly granted to Kenya by Britain in the form of loans. In addition the new government had to pay another $£ 3$ million to local non-Africans, who lost their jobs through Africanization ${ }^{31}$.

These compensation payments amounted in the early years after independence to a significant amount of the total Kenya budget. In $1963 / 64,8 \%$ of the total government spending was reserved for compensation payments and in 1967/68 the figure was still $2 \%$ of the much larger budget ${ }^{32}$. In 1972 the British Government finally agreed to take over the burden of the payment of pensions for its citizens, backdating the agreement to April 1, 1971, thus saving the Kenya Government approximately \& 2 million annually ${ }^{33}$.

The second, more important long term consequence of this rapid Africanization was that it took place within the old salary structure of the civil service. As Africans took over the posts held by expatriates, they exerted pressure on the Government to retain the colonial salary structure, even though its upper scales were geared to attract Europeans for service overseas ${ }^{34}$. The great inequalities built into the colonial salary structure were hence continued. In 1972 the highest salary in the civil service was 38 times the amount paid to the lowest position ${ }^{35}$. As justification for this large gap the civil service offered a functionalist approach matching merits and rewards for each level of employment, which was seperated by a narrow income gap from the level above and below, leading to a large overall

27 "We had the power of deportation but used it as sparingly as we could. We had to make an example of those expatriate officers who stubornly avowed open contempt ${ }^{\text {" }}$ - Odinga, Not yet Uhuru, p. 247.

28 Ndegwa Report, p. 9.

29 Compensation for "loss of career" was calculated on the basis of seniority in the service together with the number of years by which the career was curtailed. On a sliding scale it could reach £ 10-12,000 in a lump sum - Adu, Commonwealth Africa, pp. 90-94.

30 See: V. Vinnai, The Africanization of the White Highlands, Discussion Paper No. 7, Friedrich-EbertStiftung, Bonn, 1973.

31 Tom Mboya, Freedom and After, p. 134.

32 C. M. Kam'su, The Search for Economic Independence in Kenya, Paper presented at the Regional African Meeting of Directors of Development Training and Research Institutes, Nairobi (1971), mimeo.

33 Daily Nation (14. 1. 1972), p. 4, E. A. Standard (14. 1. 1972), p. 3.

34 See Ndegwa Report p. 46. The posts formerly filled by Europeans became the "senior service", those formerly held by Asians and Africans, became the "junior service".

$35 £ 4584$ annually for top positions and $£ 120$ annually for subordinate service work. 
wage differential ${ }^{36}$. Once established, such a salary structure is extremely difficult to change, for it means an attack on the country's most powerful interest group.

The third result of this speedy localization was the rapid promotion of personnel. Africans became permanent secretaries or even ministers in their thirties. Other young school leavers occupied the senior service level, thus effectively blocking the advancement for suceeding generations of civil servants in spite of their being generally better educated than their superiors. The "rates of return" for education in public sector employment are presently in the process of drastic decline. Already junior administrative grades are over supplied with candidates. These junior grades might well pressure in the future for extending incremental salary scales and reducing differentials as more people reach the top of the grade and face limited promotion prospects. A further result of declining promotion possibilities is that the tendency towards corruption, already prevelant at all levels of the service ${ }^{37}$, will increase. Moral restraints are of little value when a substantial body of public administrations feel themselves deprived of their "just rewards"

This colonial inheritance of the new Kenyan administration ${ }^{38}$ naturally strengthened the position of the Civil servants as a separate class in society ${ }^{39}$ and reinforced class divisions along economic lines especially in rural areas ${ }^{40}$.

The strength of the Civil Service as a seperate group is best seen in its rapid expansion.

36 The functional justification of these wage differentials is given in the Ndegwa Report, p. 8. See also Kenneth Prewitt, "The Functional Justification of Inequality, and the Ndegwa Report: Shaping of an Ideology". Paper presented at the USSC Conference, Nairobi (1972), Paper No. 68, mimeo, p. 8.

37 "Corruption in African Public Life" in: East Africa Journal, Vol. IV, No. 6, (November 1967), pp. 5-8.

38 The bureaucracy in Kenya is seen by Gertzel, Nellis and Okumu as more mature and powerful than other political institutions. Their argument is based on the assumption that the government bureaucracy has remained the same independent and dominant institution in society that it was prior to independence, and that administrative activities overshadow political ones because the ruling party KANU is organisationally weak.

- Cherry Gertzel. The Politics of Indenpendent Kenya, Nairobi, 1970, pp. 163-173, and "The Provincial Administration in Kenya", Journal of Commonwealth Political Studies, Vol. IV, No. 3 (1966), pp. $201-215$.

- John R. Nellis: „Is the Kenyan Bureaucracy Developmental? Political Considerations in Development Administration". "Paper for the Conference on Comparative Administration, Arusha (25-28. 9. 1971).

- John Okumu, "The Political Setting" in: Hyden/Jackson/Okumu (Eds.), Development Administration; The Kenyan Experience, Nairobi, 1970, pp. 25-42.

For an opposite view see: G. Hyden:, "Social Structure, Bureaucracy and Development Administration in Kenya ${ }^{\alpha}$, in: The African Review, Vol. I, No. 3, (January 1972), pp. 118-129.

39 The development of a special class in the form of the civil servants had been an issue in the 1966 "little" generai election and the 1969 by-election in Gem, Nyanza Province, when the now dissolved KPU attacked the salary structure of the Civil Service as promoting rapid class formation in Kenya Gertzel/Okumu, "The little General Election 1966" in: Gertzel, The Politics of Independent Kenya, pp. 73-94; and J. Okumu, “The By-Election in Gem: An Assesment” in: East Africa Journal, Vol. VI, No. 6 (June 1969) pp. 9-17'(here p. 15).

40 For an example from Tanzania, which equally applies to Kenya, see: H. U. E. Thoden van Velzen, “Staff, Kulaks and Peasants: A Study of a Political Field". In L. Cliffe and J. S. Saul, Socialism in Tanzania, Vol. II, Nairobi 1973, pp. 153-179. 
Employment in the Public Sector, 1963-1972

\begin{tabular}{|c|c|c|c|c|c|c|c|c|c|c|}
\hline & 1963 & 1964 & 1965 & 1966 & 1967 & 1968 & 1969 & $1970^{\mathrm{N}}$ & $\begin{array}{c}\text { Number } \\
1971\end{array}$ & $\begin{array}{r}000^{\prime} \mathrm{s} \\
1972^{*} \\
\end{array}$ \\
\hline $\begin{array}{l}\text { Kenya } \\
\text { Government } \\
\text { (incl. teachers) }\end{array}$ & 80.1 & 85.5 & 85.1 & 93.5 & 94.9 & 99.1 & 109.1 & 160.3 & 164.0 & 177.0 \\
\hline Parastatal Bodies &.-- &.-- & $-\ldots$ & -. - & 13.4 & 14.1 & 17.0 & 18.4 & 18.8 & 23.1 \\
\hline Local Government & 40.5 & 55.5 & 59.4 & 60.2 & 59.8 & 63.1 & 67.3 & 23.7 & 23.8 & 25.8 \\
\hline $\begin{array}{l}\text { E. A. Community } \\
\text { (General Fund } \\
\text { Services) }\end{array}$ & 3.2 & 3.1 & 3.3 & 3.1 & 3.0 & 2.9 & 2.8 & 3.1 & 3.2 & 3.7 \\
\hline $\begin{array}{l}\text { E. A. Railways } \\
\text { and Harbours }\end{array}$ & 24.1 & 23.3 & 24.3 & 26.4 & 25.4 & 25.3 & 25.1 & 24.7 & 25.7 & 26.1 \\
\hline $\begin{array}{l}\text { E. A. Posts and } \\
\text { Telecommuni- } \\
\text { cations }\end{array}$ & 4.4 & 4.5 & 4.8 & 4.7 & 4.9 & 4.8 & 4.8 & 5.5 & 5.8 & 5.8 \\
\hline $\begin{array}{l}\text { E. A. Airways } \\
\text { Corporation }\end{array}$ & 1.7 & 2.0 & 2.1 & 2.5 & 2.8 & 3.0 & 3.3 & 3.8 & 3.7 & 3.9 \\
\hline $\begin{array}{l}\text { E. A. Cargo } \\
\text { Handling Servic'es }\end{array}$ & 5.3 & 8.1 & 9.2 & 10.0 & 7.8 & 9.6 & 8.2 & 8.7 & 9.9 & 9.1 \\
\hline Total & 159.5 & 182.0 & 188.2 & 200.4 & 212.1 & 221.9 & 237.6 & 248.0 & 255.7 & 175.5 \\
\hline
\end{tabular}

("Provisional)

Source: Statistical Abstract (1972), p. 211, Table 221, Economic Survey (1973), p. 136

From 1963 the service increased from about 160,000 persons to 275,000 persons in 1972. In contrast employment in the private sector hardly changed - from 393,400 in 1964 to 397,300 in 1970 , reaching 424,000 in 1971 and 433,900 in $1972^{41}$.

Already in 1966 the public sector provided about $30 \%$ of all paid employment and for over $46 \%$ of employment outside agriculture ${ }^{42}$. By 1972 these shares had further grown to about $35 \%$ and $55 \%$ respectively ${ }^{43}$. Just as in other African countries the public service dominates the labour market.

The rapid enlargement of the Civil Service from 1963 to the present is entirely due to an increase in African staff44.

41 Economic Survey (1973), p. 135. - Employment figures in the private sector prior to 1964 were estimated by a different method and are not comparable with these for 1964 and after.

42 Economic Survey (1968), Table 8.1 p. 105.

43 Economic Survey (1973), Table 9.2 p. 135.

44 There is a suspicion amongst non-Kikuyus, that in relation to total population, Kikuyus are disproportionately represented in the middle and higher levels of the civil service. The Civil Service Staff List which would verify this claim is, however, a restricted document. See: H. Bienen, "The Economic Environment" in Iyden/Jackson/Okumu, Development Administration, pp. 55-57 - and nomic Environment" in Hyden/Jackson/Okumu, Development Administration, pp. 55-57 7 and
Donald Rotchild "Ethnic Inequalities in Kenya", Journal of Modern African Studies, Vol. 7, No. 4, (1969), pp. 689-711, esp. pp. 698-701. The issue of tribal oriented appointments to the civil service was also discussed in Parliament - Daily Nation (13. 4. 1973), p. 4. 
Employment in the Public Sector, according to race 1964-1971*

\begin{tabular}{lrrrrrrrrr}
\hline & 1963 & 1964 & 1965 & 1966 & 1967 & 1968 & 1969 & 1970 & 1971 \\
\hline African & 141.3 & 168.2 & 173.3 & 184.5 & 198.3 & 208.8 & 226.0 & 236.8 & 245.1 \\
\hline A.sian & 11.9 & 8.8 & 9.5 & 10.6 & 8.5 & 8.0 & 7.4 & 7.0 & 6.4 \\
\hline European & 6.3 & 4.9 & 5.4 & 5.3 & 5.3 & 5.0 & 4.2 & 4.2 & 4.2 \\
\hline Total & 159.5 & 182.0 & 188.2 & 200.4 & 212.1 & 221.9 & 237.6 & 248.0 & 255.7 \\
\hline
\end{tabular}

(" - The figures for 1972 are not available)

Source: Statistical Abstract 1972, Table 219, p. 210

From late 1963 until early 1966 every available African graduate could get a job in the civil service - whether trained or not ${ }^{45}$. In view of its power, prestige, security and income, it is not surprising that most educated Africans choose the civil service as a career.

As Africans dominated the service, the number of Asians declined from 11,900 in 1963 to 6400 in 1971, in the same period the number of Europeans was reduced from 6300 to 4200 .

Whereas the Europeans serving in Kenya prior to 1963 represented a fairly homogenous group - the British Colonial Civil Service - and occupied approved posts financed through local taxation, those serving in 1973 were mainly technical assistance personnel coming to Kenya under various foreign aid schemes. This changing composition of Europeans in the service is the result of changes in their functions. As Africanization increased the number of non-citizen personnel with executive power declined in Kenya by 633 persons from 1966 to $1972^{46}$. But the number of advisors and educational experts including volunteers increased over the same period by 1133 persons ${ }^{47}$.

In Kenya the total number of foreign experts rose from 2902 in 1966 to 3372 in 197048. In October 1972 the foreign aid personnel in Kenya numbered already 3589 of which 595 were advisors in various ministries, 115 were volunteers and 2279 were technical officers, who held professional positions for which at present no Kenyans are allegedly qualified to replace them ${ }^{49}$.

The degree of Kenyanization of the Public Sector in 1972, whereby citizen is virtually synonymous with African, is given below:

\footnotetext{
45 Leys/Stamp, Organization and Development, Chapter II, p. 15 - the crash programme of the Kenya Institute of Administration ended in 1968, when all junior and middle executive posts had been Africanized.

46 From 1341 to 678; Development Assistance (1971), OECD Review, Table 13, pp. 180, 181. 47 Ibid. pp. 180,181

Advisurs (OECD countries)

Advisurs (Multilateral Organizations)

Educational Experts

Volunteers

48 Ibid.

Total

$\begin{array}{cc}1966 & 1970 \\ 206 & 412 \\ 102 & 161 \\ 789 & 1165 \\ 464 & 956 \\ 1561 & 2694\end{array}$

49 Daily Nation, (7. 10. 1972), p. 6.
} 
Degree of Kenyanization in the Public Sector by Occupation (1972)

\begin{tabular}{lrrrrrr}
\hline & \multicolumn{2}{c}{ Total } & \multicolumn{3}{c}{ Citizens } & Non-Citizens \\
\hline Managerial occupations & No. & $0 / 0$ & No. & $\% / 0$ & No. & \%/0 \\
\hline Professional occupations & 380 & 100 & 340 & 95,5 & 40 & 10,5 \\
\hline Semi-professional or technical occupations & 21,100 & 100 & 17,520 & 83,0 & 3,580 & 17,0 \\
\hline Skilled office and clerical occupations & 11,940 & 100 & 10,580 & 88,6 & 1,360 & 11,4 \\
\hline Skilled manual occupations & 4,900 & 100 & 4,420 & 90,2 & 480 & 9,8 \\
\hline Total high and middle level manpower & 41,039 & 100 & 34,204 & 83,3 & 6,835 & 16.7 \\
\hline
\end{tabular}

Source: A Preliminary Report on the Kenya High and Middle Level Manpower Survey (1972), Table 4 in: Kenya Statistical Digest (Vol. X, No. 4, Dec. 1972)

However the government still hopes to Africanize these posts ${ }^{50}$ well before 1982, the target set in the Development Plan for 1970/7451.

\section{The Teaching Sector}

One special group among the civil servants are teachers for whom formal education of varying length is a prerequisite. At independence Europeans occupied the university posts ${ }^{52}$ and many leading positions in the secondary school sector, in which Asians provided almost $50 \%$ of the entire staff53. Africans mostly supplied the teaching body of primary schools.

The need to expand the educational sector after independence in order to increase the output of pupils at all levels of the educational system dictated a slow pace of Africanization. The supply of trained Africans for teaching positions was primarily needed to fill newly created posts in the expanding system. From 1963 to 1972 the teaching body of both primary and secondary expanded enormously ${ }^{54}$, while the number of non-citizen teachers hardly changed.

In primary schools the number of non-citizen teachers dropped from 1420 in $1966^{55}$ to 790 in 1972, whereas those in secondary schools increased from 1964 to 2662 persons. In the same period the percentage of citizen teachers in primary schools rose from $96 \%$ to $99 \%$ and in secondary schools from $37 \%$ to $63 \%$.

By 1972 the localization of primary school personnel is nearly completed. Noncitizens, mostly Asians who at independence retained their British citizenship, are

\footnotetext{
50 The reluctance prevailing in some African countries to Africanize the bureaucracy totally, partly due to a suspicion concerning the political role the highly educated young cadres might play and partly due to economic considerations (Africanization would mean payment of salaries out of the local budget, whereas foreign personnel was available at little or no cost) is not apparent in Kenya.

51 Development Plan 1970-74, p. 121.

52 The University of East Africa (founded in June 1963), combined Makerere University College in Kampala (founded in 1922), the former Royal Technical College in Nairobi (founded in 1956) and the newly established (1961) University College in Dar-es-Salaam. In 1970 the University of East Africa ceased to function when each of the three countries established its own university.

53 Symonds, The British and their Successors, p. 176.

$\begin{array}{lcrrr}\text { School Teachers } & 1963 & 1966 & 1969 & 1972 \\ \text { Primary Schools } & 22,772 & 33,522 & 38,312 & 53,536 \\ \text { Secondary Schools } & 1.530 & 3104 & 5276 & 7601 \\ \text { Source: Ministry of Education, Anual Reports }\end{array}$

Source: Ministry of Education, Auual Reports and Economic Surveys.
}

55 Prior to 1966 no figures are quailable acording to citizenship. 
now being replaced by Africans. In February 1973 the removal of 428 non-citizen primary teachers was announced ${ }^{56}$ leaving about 360 positions still to be localized.

In the secondary school sector Africanization increased sharply after 1971. Since non-citizens here occupied positions which blocked the advancement for many Africans, the expulsion of the Asians from Uganda brought strong pressure to remove Asian non-citizen teachers also in Kenya. In June 1972 about 400 secondary teachers, mostly Asians lost their jobs ${ }^{57}$. The irony of sacking Asians from school service is at present the increased dependence upon Europeans from abroad, many with poor English and a total ignorance of Kenya.

In December 1972 the Kenya National Union of Teachers demanded immediate Africanization of all heads of schools in the country ${ }^{58}$.

It can be expected that all non-citizen school teachers - except those teaching under technical aid arrangements ${ }^{59}$ - will be replaced within a relatively short period.

The situation in higher education is rather different. Due to the long period of formal education required of the teaching staff, the degree of Kenyanization in teaching, in contrast to its administration, varies from institution to institution and from faculty to faculty. The Manpower Survey of 1967 enumerates "University Teachers" according to citizenship and race as follows:

\section{University Teachers in 1967}

\begin{tabular}{lcccccccc}
\hline & Total & \multicolumn{3}{c}{ Non-Citizen } & & Citizen & & $\%$ of \\
& & African & Asian & Europ. & African & Asian & Europ. non-citizen \\
\hline Arts & 154 & 3 & 11 & 90 & 50 & - & - & 67,5 \\
\hline Science & 102 & 4 & 4 & 65 & 25 & 1 & 3 & 71,5 \\
\hline
\end{tabular}

Source: Statistical Abstract 1970, Table 196, p. 176

The Manpower Survey of 1972 lists "High Level Teachers" only according to citizenship:

High Level Teachers in 1972

\begin{tabular}{lcccc}
\hline & Total & Non-Citizen & Citizen & $\begin{array}{c}\% \text { of } \\
\text { non-citizen }\end{array}$ \\
\hline Arts & 103 & 58 & 45 & 56.3 \\
\hline Science & 133 & 71 & 62 & 53.4 \\
\hline
\end{tabular}

Source: Preliminary Report - Manpower Survey 1972, Table 1, p. 7

Since the two survey results are only of limited value for our purposes, a more detailed picture according to institution is presented.

The progress of localization of the teaching staff in Kenya's Teachers' Colleges and at the Kenya Polytechnic are given below:

\footnotetext{
56 Sunday Post (11. 2. 1973), p. 1.

57 Daily Nation (1. 6. 1972), p. 9. The reasons given for retiring non-citizen Asians are highly suspect. The Chairman of the Teachers Service Commission, Z. Mwangi, gave an example of the unsuitability of Asian teachers which reveals a strong racial bias. An Asian teaching English, he stated, was at a disadvantage because English was a second language to him-Interview Daily Nation (1. 6. 1972), p. 9. 58 E. A. Standard (16. 12. 1972), p. 1 .

59 In 1970, 1058 "educational experts" and 455 volunteers worked as teachers in Kenya - OECD Review?:1971), p. $180,181$.
} 
Localization of Teaching Staff

\begin{tabular}{lccccc}
\hline & Year & Citizen & \multicolumn{2}{c}{ Non-Citizen } & \multicolumn{2}{c}{ Total Staff } \\
& & & Local Terms & Overseas Terms \\
\hline Teachers' Colleges & 1964 & 146 & & 170 & 316 \\
\hline & 1966 & 167 & 101 & 134 & 402 \\
\hline & 1969 & 223 & 147 & 152 & 522 \\
\hline & 1971 & 445 & 130 & 130 & 705 \\
\hline Kenya Polytechnic & 1966 & 1 & 18 & 41 & 60 \\
\hline & 1969 & 21 & 18 & 68 & 107 \\
\hline & 1971 & 36 & 24 & 73 & 133 \\
\hline
\end{tabular}

Source: Ministry of Education, Annual Summaries

Whereas the non-citizen staff of the Teachers' Colleges is slowly declining, that of the Polytechnic is still rising indicating not only the greater extent of specialized education required of the staff in the latter institute, but also the expansion of the Kenya Polytechnic due to the great demand for technical education.

In the academic year 1967/68 the academic staff at the University of Nairobi consisted of 128 expatriates, 46 locals and 25 special lecturers ${ }^{60}$, positions set up for mature scholars who are or soon will be fully qualified for established posts in the University ${ }^{61}$. Of the permanent staff $74 \%$ were foreigners and $26 \%$ locals $^{62}$. The expansion of the University of Nairobi from 1967/68 to October 1972 can be seen in the next table:

\section{University of Nairobi}

\begin{tabular}{lcccc} 
Faculties/Institutes/Schools & Posts & Filled & Vacant & Africans \\
\hline Faculty of Engeneering & 59 & 45 & 15 & 14 \\
Faculty of Arts & 77 & 60 & 17 & 33 \\
Faculty of Architecture & 32 & 16 & 17 & 1 \\
Faculty of Education & 25 & 13 & 9 & 12 \\
Faculty of Commerce & 24 & 14 & 10 & 1 \\
Faculty of Agriculture & 22 & 17 & 5 & 8 \\
Faculty of Science & 62 & 45 & 16 & 23 \\
Faculty of Law & 20 & 14 & 6 & 9 \\
Institute of Adult Studies & 28 & 21 & 7 & 17 \\
Institute for Development Studies & 6 & 4 & 2 & 4 \\
School of Journalism & 4 & 3 & 1 & 2 \\
Faculty of Medicine & 109 & 73 & 35 & 29 \\
Faculty of Veterinary Medicine & 65 & 47 & 18 & 21 \\
Institute of African Studies & 6 & 5 & 1 & 4 \\
\hline
\end{tabular}

Source: Unpublished Statistic, University of Nairobi, 24. 10. 1972

\footnotetext{
60 A. S. Awori, “East African Universities must be Africanized”, East Africa Journal, Vol. IV, No. 8 (December 1967), p. 22.

61 Ibid, p. 19.

62 Ibid, p. 22.
} 
Of the 381 posts listed above as filled, 351 were in the teaching department and 30 in the research institutes. Of all academic posts only 179 or $46 \%$ were filled by citizens. Of the teaching posts citizens occupied 154 or $43 \%$.

In the three institutes attached to the university, $80 \%$ of the established posts went to citizens. This figure is, however, quite misleading since at the Institute for Development Studies only six of the 30 positions are budgeted. The rest of the research staff are foreigners working in Kenya under various aid schemes at none or minimal costs to the university.

The situation at the university is also characterized by a great number of vacancies - of the total 540 established posts 159 are vacant - and the variations between the faculties. However, in comparing these figures it must be borne in mind that most of the technical departments as well as those in fields like medicine were quite recently established, whereas most in the Faculty of Arts or Science existed since the early years of the university. With the future expansion of the university, the target is to increase the student population by $10 \%$ every year ${ }^{63}$, the Africanization of teaching staff will proceed at a slow pace.

\section{Conclusion}

In the previous discussion only one aspect of localization, the replacement of foreign personnel by Africans, was discussed. Localization of the Civil Service has so far meant largely the Africanization of posts - the replacement of Whites by Africans. Virtually no attempt has been made to change the practices and procedures of the administrative system itself and, indeed, the question of whether a British type civil service is most suitable for Kenya's needs has hardly been posed. Africanization has in no way altered the structure of the civil service, but only its personnel64.

The problem of localization beyond a change of staff is even more important in the schools. Here, what is sometimes referred to as academic imperialism ${ }^{65}$ continues. One aspect of this domination, employment of expatriates within the universities, has been discussed. The second aspect is the continuation of an ethnocentrism of western education for Africans, which implant in the student a western outlook and way of thinking. For most students leaving the university, to be educated means equally to be "westernized". However, a futile debate on how to change the syllabus at all levels of the school system to suit the needs of the African population has been raging for decades ${ }^{6}$. Nevertheless, the first books written specifically for African students - even though almost exclusively produced by expatriates teaching in Africa - have appeared and are used in the schools ${ }^{67}$.

63 Interview Vice President Karanja - quoted in Sunday Nation (8. 7. 1973), p. 5 - In September 1973 the university plans to send a mission to overseas countries to try and recruit as many Kenyans

64 A. H. M. Kirk-Greene, "The New African Administrator", in: Journal of Modern African Studies,

65 Burt 10, No. 1 (1972), pp. 93-107. Adams, "Africanization and Academic Imperialism: A case study in planned change and inertia", in: East Africa Jciurnal, Vol. IX, No. 5, (May 1972), pp. 23-28.

66 In 1966 a Curriculum Development Center was established to analyse the existing curriculum for primary and secondary schools and to recommend modifications and changes. For a detailed treatment of the Africanization of the curriculum in the colonial and independence period see: G. Urch, “The Africanization of the Curriculum in Kenya", Dissertation University of Michigan, Ann Arbor, 1967.

$67 \mathrm{E}$. g. the series of undergraduate teaching works in Economics from Makerere College, Kampala published by Oxford University Press, Nairobi; for details see: Helen Kimble, "On the Teaching of Economics in $\Lambda$ frica", Journal of Modern African Studies, Vol. 7, No. 4 (1969), pp. 713-741. 
The third aspect of academic imperialism, the use of African countries for research and professional ends by western scholars, has been recognized in Kenya for the last two years. Research in Kenya which enhances only the reputation abroad of those who undertake it but with little use to the needs of the country studied is now discouraged through the refusal of permits to conduct research in Kenya ${ }^{68}$.

Africanization in this other sense of re-shaping institutions as distinct from replacing expatriates is now, 10 years after independence, at last being recognized. With the Africanization of personnel in the civil service including the teaching sector being completed in the next decade, those other aspects of localization will perhaps be better indentified and remedied.

68 All research piojects carried out in Kenya need prior approval of the Office of the President. 


\title{
The Creation of an African Civil Service in Kenya
}

\author{
By VolKer VinNaI
}

Prior to independence the Kenyan civil service was primarily occupied with the collection of revenue to make the colony selfsupporting, with the maintenance of law and order and the creation of favourable conditions for the White agricultural sector and its supporting infrastructure. In Kenya Europeans filled the top posts in the service, the middle level was occupied by Asians, whereas Africans were recruited only for the jobs at the bottom. Even thoug they represented 80 per cent of the entire service in 1960 Africans occupied few of the better paid jobs.

With the approach of independence the colonial government started a rapid Africanization programme which transformed the service from a colonial one with limited functions into a national one geared to the economic and social development of the country and its African population. Shortly after independence virtually the entire administrative cadre of the service was filled with Kenya citizens, mostly Africans.

This speedy Africanization led to three long term consequences. First, the forcible retirement of British civil servants created a large financial commitment for the new state, which was finally terminated in 1972 when the British government took over the payment of pensions for its citizens. Second, Africanization took place within the old salary structure even though its upper scales were geared to attract Europeans for service overseas. Finally this rapid Africanization blocked the avenues of advancement for those who joined later even though they are better educated than their superiors.

Localization of the civil service has so far meant largely the Africanization of posts - the replacement of Europeans and Asians by Africans. Virtually no attempt has been made to change the practices and procedures of the administrative system. Africanization has in no way altered the structure of the service but only its personnel.

Kenyanization in the sense of re-shaping of institutions to serve local conditions and demands as distinct from replacing expatriates is now at least being recognized. With the Africanization of personnel almost completed, those other aspects of localization will perhaps be identified and remedied.

\section{Origin and Substance of the Iranian Constitution}

\section{By Mehdi Tohidipur}

We have seen that the Iranian Constitution, which came into effect immediately after the end of the Constitutional Movement (1906), was drafted in the euphoric atmosphere of victory and represented an establishment of the middle class with feudal remnants. It reflects the political importance of the groups which participated in its founding, i. e. the liberal Left, the conservative-liberal urban middle class, and the conservative islamic-shiit clergy. The form and normative substance of the Iranian Constitution therefore may be regarded as the autobiography of a political and economic balance of power in a specific historical and 